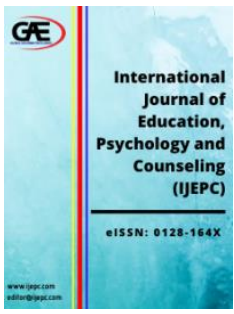

\author{
INTERNATIONAL JOURNAL OF \\ EDUCATION, PSYCHOLOGY \\ AND COUNSELLING \\ (IJEPC) \\ www.ijepc.com
}

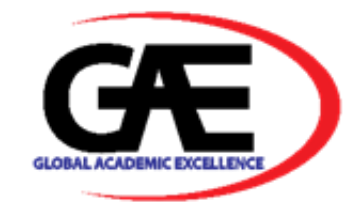

\title{
EFFECTIVE APPROACH, WORK-RELATED CONTENT AND OPPORTUNITY TO PURSUE HIGHER EDUCATION OF SCIENCE CORE SUBJECTS
} \author{
Panessai ${ }^{4}$, Ramlan ${ }^{5}$ \\ 1 Department of Educational Studies, Universiti Pendidikan Sultan Idris, Malaysia \\ Email: razimi@fpm.upsi.edu.my \\ 2 Department of Educational Studies, Universiti Pendidikan Sultan Idris, Malaysia \\ Email: hishamuddin.a@fpm.upsi.edu.my \\ 3 Department of Psychology and Counseling, Universiti Pendidikan Sultan Idris, Malaysia \\ Email: bazlan@fpm.upsi.edu.my \\ 4 Department of Computer, Universiti Pendidikan Sultan Idris, Malaysia \\ Email: ismail@fskik.upsi.edu.my \\ 5 Faculty Teaching and Educational Sciences, Universitas Pasundan, Bandung, Indonesia \\ Email: ramlanmsn@unpas.ac.id \\ Corresponding Author
}

Mohd Razimi Husin ${ }^{1 *}$, Hishamuddin Ahmad ${ }^{2}$, Muhammad Bazlan Mustafa ${ }^{3}$, Ismail @ Ismail Yusuf

\section{Article Info:}

\section{Article history:}

Received date:23.09.2020

Revised date: 17.09 .2020

Accepted date: 18.10 .2020

Published date: 03.12.2020

\section{To cite this document:}

Husin, M. R., Ahmad, H., Mustafa, M. B., Panessai, I. Y., Ramlan. (2020). Effective Approach, Work-Related Content and Opportunity to Pursue Higher Education of Science Core Subjects. International Journal of Education, Psychology and Counseling, 5 (37), 138-146.

DOI: $10.35631 /$ IJEPC.5370011.
Abstract:

This paper presents the most effective approach used by teachers for the core subjects of Science, work-related learning content, and its future functions for humanities students in Sijil Pelajaran Malaysia. Previous research indicates there is a teenager that does not have a career to choose although they have a high academic performance. Moreover, there are teenagers who chose a career which have less relevance to the stream chosen at school. In this study, certain effective techniques and the very related contents of science core subject to future works has developed. This study uses a qualitative approach which involves interviews that are analysed using Nvivo software. The qualitative approach uses phenomenological design to reflect on the experience of the former students towards their experience and learning contents of secondary school upper-level science core subject which impacted their career aspirations today. Twelve experienced workers were selected through purposeful sampling. The results show that there are certain techniques that are very effective for teachers including the use of certain learning aids and science laboratories. Meanwhile, respondents who obtained very good examination results were less able to take advantage of Science Subjects in Sijil Pelajaran Malaysia (MCE) because most higher learning institutions tend to choose 


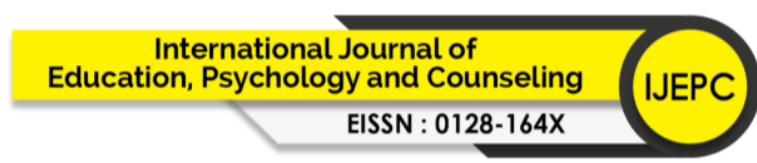

Volume 5 Issue 37 (December 2020) PP. 138-146

DOI 10.35631/IJEPC.5370011

This work is licensed under $\underline{\text { CC BY 4.0 }}$ students who have biology or more relevant subjects in certain courses. This (c) (1) study has revealed effective learning experience techniques that are beneficial for all educators and also shows the lack of function of this science subject to students with excellent achievement.

Keywords:

Core Subjects Of Science, Teaching Techniques, Pedagogical Practices And Curriculum

\section{Introduction}

The implementation of teaching and learning which emphasize on the effective learning experiences and effective learning content to students future life is very important. Aspects of the effective learning experiences and effective learning content that taking into account student career aspirations are necessary to meet the findings of study that is learning to meet the requirements of their employers (Tladinyane \& Merwe, 2016). The kind of learning are taking into account of having a chosen career for future profession, having a sense of care, aware of the characteristics of their choice of career and confident in their ability to perform their chosen career (Tladinyane \& Merwe, 2016). However, there is no specific research for getting data from experienced workers for it to be use as a guide. The new curriculum implemented addresses the content that is required to be delivered to the students based on their core and stream of the students (Sampangi \& Siegel, 2019). One of the subjects that SPM students must take is Science. According to Tripney, Newman, Bangpan, Niza, MacKintosh and Sinclair (2010), improvement in the education system in science is a key element in strengthening Science education. This requires a strategic framework to support the science and future careers of students (Jufrida, 2019). Tripney et al. suggest that adolescents make career choices at the next school level. Based on past studies of effective Science learning experiences, it is through hands-on methods (Peterson \& Scott, 2018;. Walan, 2017; Hubahib, 2016). In addition to methods of hands-on activity simulation, games, teamwork, responsibility, collaborative learning and problem-solving activities are methods that enhance students' understanding of Science subjects (Balasubramaniam, 2006; Chetty, 2019; Zenda, 2017; Crebert, 2004; Wamb \& Dunn, 2009; Goethe, 2019; Widodo, 2016). Besides, the effective approaches to the medium level of students in Science core subject are regulating the use of laboratories, organizing them with tactical activities and appreciating using the organ learning tools (Razimi, 2020). It is the greater responsibility of education authorities and implementer in national education to implement content knowledge in the most effective way and benefit the future of students. The willingness to do something beneficial and implementing the appropriate improvements will enhance the quality of knowledge presented and the use of certificates from public examinations for the purpose of applying for appropriate courses to students further their study. Students' knowledge and skills begin at school through the lesson at school, but some program were not present to students with active participation, different methods and techniques, meaningful learning, and different resources (Behrendt \& Franklin, 2014). Out-of class activities created and associated with past historical events help students easily receive information, and similarly, this approach gives students confidence to present learning content after a discussion session with peers (Ayvaz-Tuncel \& Tuncel, 2019). Stream selection occurs to students in secondary school starting in form four especially. However, the chosen stream may not necessarily build a career aspirations in their soul (Husin, 2020). Some of them want to work in an area that are less relevant to their chosen stream. Sometimes certain subjects become a source for students to pursue a career and current field 


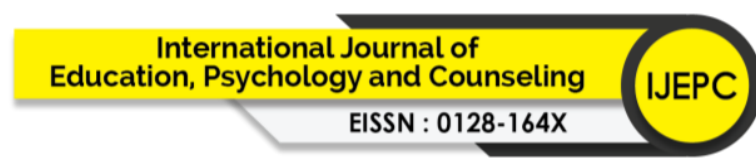

Volume 5 Issue 37 (December 2020) PP. 138-146

DOI 10.35631/IJEPC.5370011

selection at the tertiary level. Students will learn something meaningfully if they are able to make their knowledge gained in school as a path to their future lives as well as the objectives of Kurikulum Bersepadu Sekolah Menengah (Secondary School Integrated Curriculum) and Kurikulum Standard Sekolah Menengah (Secondary School Standard Curriculum) (Kementerian Pendidikan Malaysia, 2015). Therefore, the school curriculum is constantly changing according to current needs. Research is needed not only on the students' knowledge, but also a developed curriculum that can contribute to the future needs and careers of students. Therefore, this paper present a selected science subject as a study's set because it is a core subject for the humanities stream students. However, this research does not look at the selection of student streams, but tries to reveal more in depth about the relevance of one subject i.e. core science to employment and its impact on students for their future. In addition, revealing effective learning experiences according to the views of former students who have work experience.

\section{Literature Review}

Some teenagers are found to have problems while choosing a higher education program to fulfill their desired career. According to Gutman and Schoon (Gutman \& Schoon, 2012), there are teenager with uncertain career aspirations to have high academic performance at the age of 16. Likewise, teenager who have a low performance are likely to have uncertain career aspirations (Gregor, 2017). The objective of the Ministry of Education (MOE) is to hope that the knowledge and skills acquired by students can help them in their daily lives and career choices. This step has been implemented through the application of skills in the Vocational College Curriculum. However, the stream of upper secondary schools education in MOE whether science, humanities or accounting is not a determinant of career choice for some students. According to Ismail, Kadir and Pihie (2011), accounting stream students do not necessarily want to work in the accounting field. Therefore, stream selection in school are not determinants to future careers for some students. Emphasis on a subject need to be given attention so that it can contribute to students career. The findings confirmed that education aspirations is one of the factor in understanding career aspirations among the younger generations (Gregor, 2017). However, there are still students who still do not have career aspirations and the future even though they are already in upper secondary level. Therefore, it has become one of the purposes of this research to look at the needs of national educational aspirations in 21 st century learning. Each learning content has its own importance in everyday life. However, implementing the right strategy will determine its effectiveness (Jony, 2019). Core science is a compulsory subject that must be taken by all humanities students in the Malaysian Student Certificate (MCE). Therefore, the content, learning experience and its function as a condition of requirement to choose a particular course or program in higher education is something that needs to be given serious attention. Individual learning content and experience are inadequate if they are only able to apply what they have learned while disregarding its needs in daily life or future use (Wijaya, \& Bukhori, 2017). Studying in school is not just about passing an exam. The 21st century education emphasizes on learning for life (Shola, 2019). Therefore, the education body should pay more attention to this matter. Mainstream school students should be given special attention on the importance of subjects that are a requirement to be taken in MCE which can provide opportunities in terms of continuing education and career opportunities. As such, this research look at in depth the relevance of core science subject to employment and its impact on students for their future. In addition, revealing effective learning experiences according to the views of former students who have work experience. Those who got lower achievement in school for science core 


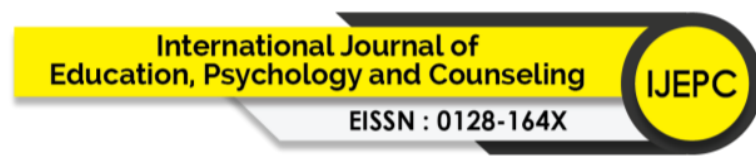

Volume 5 Issue 37 (December 2020) PP. 138-146

DOI 10.35631/IJEPC.5370011

subject does not have future aspiration during school age and work based on opportunity surround them.

\section{Research Method}

This research used a qualitative approach involving interviews and documentation analyzed using NVivo software. This research is a cross-sectional study involving former high school students over 5 to 10 years of finishing school and having their own careers. The qualitative approach in this research uses phenomenological design to describe students' experiences of the effective techniques uses by teachers of upper secondary learning for science as well as career related to the experience and content of learning in the subject and its opportunity to tertiary learning and career. To measure the career aspirations of this research, participants were asked to answer open questions adapted from the career aspirations questions by Creed, Buys, Tilbury and Crawford (2013). 4th International Conference on Islamic Education and Law 2020 (4th ICIEL 2020) eISBN 978-967-2426-08-0 29th - 30th August 20204 The qualitative approach in this study emphasizes interviews and documentation. In collecting and analyzing data, researchers will use coding, refining, categories and concepts linking and develop theories as suggested by Merriam (2001). The research participants were selected as intended in the study of Madzniyah Md Jaafar and Mohd Razimi Husin (Husin, Shukor \& Jusoh 2011; Shukor, Husin \& Jusoh, 2015; Husin, 2017; Husin, 2018a; Husin, 2018b). The information is processed by reduction or screening, coding and verification, and is analyzed based on themes performed according to the study participants. One of the strategies in this approach is to concentrate on information that may produce large amounts of data initially and remove the less important information as suggested by Miles and Huberman (Miles, \& Huberman, 1984). The interviews to be conducted are semi-structured whereby the questions draft are provided as guidelines and are conducted individually. Interview data will be transcribed into text form for easy data interpretation. Researchers interviewed 12 former secondary school students who took Science as their core subject. They were selected by purposive sampling to obtain clear information on one to three research questions. This research is a design that has the phenomenon that needed to be researched and the context of research (Idris, 2010). Examples of the phenomena that are examined are the learning activities, titles and knowledge of form four and five that have a lot to do with their daily life, further study opportunity and career life.

\section{Results and Analysis}

Based on observations made on Science subjects to support the literature review or vice versa, this shows that some learning experiences are effective according to the views of former students who have work experience. This research reveals more deeply the relevance of core science to employment and its impact on students for their future. Effective approaches include the use of real and practical learning aids in the laboratory room. Although some topics have to do with their work, the relevance is not so great. The vast majority of respondents do not have a relationship between these subjects with the opportunity to choose related fields at the tertiary level and their careers. There are also participants who tend to pursue education related to this science, but the core science subjects do not allow them to qualify to continue their field of interest to a higher level of education. The Most Effective Approach in Teaching and Learning There are a number of sub-topics in upper secondary Science subjects that apply a specific approach to students so that they still remember the content to this day despite more than five years of study. The approach includes the use of real and practical learning aids in the laboratory room such as do case studies using tools, dissecting rats and frogs. Apart from using 


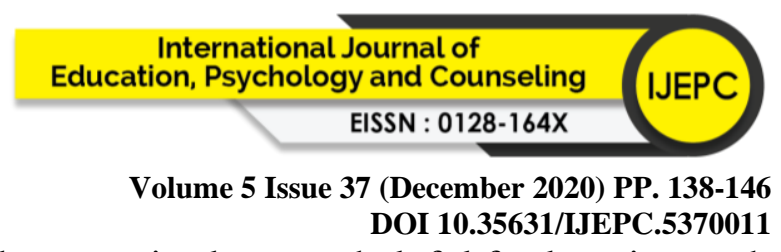

real learning aids practicum in or outside the laboratory is also very helpful for learning such as mixing certain colors to produce new colors. In addition, the appearance and personality of teachers also play an important role in attracting the interest and inclination of learning to love science and improve mastery and skills in core science subjects as shown in Table 1.

Table 1: The Most Effective Approach

\begin{tabular}{|c|c|c|c|c|c|c|c|c|c|c|c|c|}
\hline Effective Approach & P1 & $\mathbf{P 2}$ & P3 & $\mathbf{P 4}$ & $\mathbf{P 5}$ & P6 & $\mathbf{P 7}$ & P8 & P9 & \multicolumn{3}{|c|}{ P10 P11 P12 } \\
\hline $\begin{array}{c}\text { Practicum in or Outside the } \\
\text { Laboratory }\end{array}$ & I & I & I & / & I & I & I & I & I & / & I & 1 \\
\hline $\begin{array}{c}\text { Real Learning aid } \\
\text { Teachers' Personality }\end{array}$ & l & / & I & / & I & / & l & / & / & l & l & / \\
\hline
\end{tabular}

\section{Work-related Learning Content}

As a teacher of English, knowledge learned at school in science subjects can be used by teachers to deliver Malay Language subject for students build poem and essay. However for participants working at the airport, associating their current work with fluid elements, various fluids to aircraft, luggage should be monitored. While the internal organs such as the use of the brain, lungs, liver and intestines are highly health-related organs and serve a great role in promoting daily activities such as breathing, poaching and body toxins according to information provided by the study participants:

Teachers bring things, like puppets, hearts, bowels, he shows them all to us ..

.. come to think of it. There must be some connection there between organ and our job.

Organ works for all human life including work.

Overall, it has to do with work in moderation and not directly as it relates only to minor things as shown in Table 2.

Table 2: Work-Related Level

\begin{tabular}{ccccccccccccc}
\hline Work-Related Level & $*$ P1 & P2 & P3 & P4 & P5 & P6 & P7 & P8 & P9 & P10 & P11 & P12 \\
\hline $\begin{array}{c}\text { High } \\
\text { Moderate } \\
\text { Low }\end{array}$ & $/$ & $/$ & $/$ & $/$ & & & & & & & & \\
\hline
\end{tabular}

*P1- Participant 1

\section{Opportunity to Pursue Higher Education and Career}

This is not so much discussed for lower achievement students, but a rather big impact on students who obtain good achievement in science subjects and are interested in science-related fields. Participants who obtained very good examination results were less able to take advantage of Science Subjects in Sijil Pelajaran Malaysia (MCE) because most of higher learning institutions tend to choose students who have biology or more relevant subjects in certain courses. So, some students unable to pursue in a field of interest the qualifying effect that does not take into account the core subjects of science as shown in Table 3. 
Table 3: Students' Areas of Interest Do Not Take Into Account Core Science Subjects

\begin{tabular}{ccccccccccccc}
\hline Contents & *P1 & P2 & P3 & P4 & P5 & P6 & P7 & P8 & P9 & P10 & P11 & P12 \\
\hline $\begin{array}{c}\text { Areas of interest don't take } \\
\text { into account the subjects }\end{array}$ & & & & & & & & $/$ & & & $/$ & \\
\hline *P1- Participant 1 & & & & & & & & & & & & \\
\hline
\end{tabular}

\section{Discussion}

This study found that, the relationship of core Science subjects with employment is not very encouraging. In addition, it does not support certain areas of higher education. Therefore, it is suggested that this subject be adapted and be able to support the needs of students to further their studies in the field of interest. Since most students who get low grades in this subject do not use this subject directly for their careers, it is recommended that the curriculum be appropriate and beneficial for those who need it. Relevant parties such as the Ministry of Education Malaysia at least allow qualified students to take biology subjects or build a subject that is comparable to biology in order to get satisfaction jod in future. (Hee, Shi, Kowang, Fei, \& Ping, 2020).

Although student achievement is fair in science core subject, the long-term impact is important so that the knowledge gained in school can be leveraged later. It will expect that education will become more meaningful and national education institutions will excel in such a way of learning. The fact in science should not be a tentative but inspire student to think of career. It is understood that all science information is tentative and can be evolving. It is the role of teachers to keep students experiential to develop meaningful contextual information. Teachers and researchers should not be shy about saying or doing so, both to those in schools and to those in charge of schools (Editors, 2017). Teachers also need to move from the old-fashioned approach to pressures appropriate to 21 st century education. Previous study shown that top management leadership that had career aspiration as early as in school age, but the ex-students with lower achievement and did not have future aspiration was discovered to have the uncertainty in their career. In a nutshell, what is valued in science subject is what is considered relevant in the student's context that influences their lives (Franco, 2020).

The responsibility of teachers is very much needed to teach middle class students because most students are in this circle (Barros, 1985). The effective approaches to the medium level of students in Science core subject are regulating the use of laboratories, organizing them with tactical activities and appreciating using the organ learning tools. Fluid and organs are the most learning content that related to work. Teachers should have an ideal way to teach students how to use self-monitoring strategies such as a study that focuses on the importance of monitoring and self-efficacy strategies that help students practice them (Ueki, 2013). Teaching in the classroom should relate to daily life or the outside actual situation including at workplace. In science, there are many syllables that can be directly related to work. Examples of jobs related to science and everyday life is nursing (Tsuda, 1974). Participants who obtained very good examination results were less able to take advantage of Science Subjects in Sijil Pelajaran Malaysia (MCE) because most of higher learning institutions tend to choose students who have biology or more relevant subjects in certain courses. Open choice should be given to students especially popular subjects such as biology so that they have the right choice to choose a field in higher education and future career. 


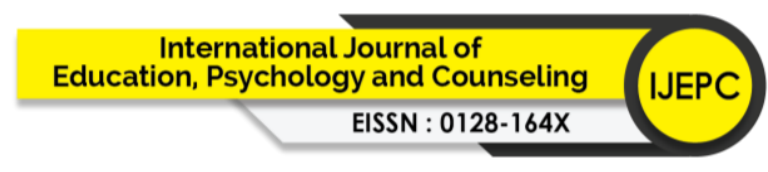

Volume 5 Issue 37 (December 2020) PP. 138-146

DOI 10.35631/IJEPC.5370011

\section{Conclusion}

This paper presents science-related aspirations of career based on learning content in Upper Secondary Level. Core Science subject teachers should use the most appropriate approach to students. Such an approach is like using existing-real learning aids and doing practical in the laboratory especially for topics that are very related to the daily routine of students and future prospects to students. According to previous studies, teachers should have appropriate methods to teach students how to use self-monitoring strategies. However, the low achievement students required more guidance from teachers than self-monitoring. In science, there are many syllabus that are directly related to occupations such as nursing. But on the other hand, the core Science subject will not qualify students to venture into the field of nursing according to the qualifications of nurses in some universities. Just offer biology or science agriculture to all humanities students is better to some excellence students.

\section{Acknowledgements}

This paper is based on the research project entitled Aspirasi Kerjaya Berasaskan Pengalaman dan Kandungan Pembelajaran Sains Pelajar Menengah Atas. The authors would like to extend their gratitude to Universiti Pendidikan Sultan Idris for the University Research Grants Based on Education (code: 2019-0080-107-01) that helped fund the research.

\section{References}

Ayvaz-Tuncel, Z. \& Tuncel, I. (2019). Good teacher perceptions of students attending the pedagogical formation certificate program. International Journal of Evaluation and Research in Education (IJERE), 8(1), 165-172. doi: org/10.11591/ijere.v8i1.17093

Balasubramaniam, N. (2006). Innovative Methods of Teaching Science and Engineering in Secondary Schools. International Journal of Educational Development, 50, 165-177.

Barros, M. (1985). Teachers' responsibility in the education of medium-level personnel. Revista brasileira de enfermagem, 38, 95-100.

Behrendt, M. \& Franklin, T. (2014). A Review of Research on School Field Trips and Their Value in Education. International Journal of Environmental \& Science Education, 9, 235-245. doi: 10.12973/ijese.2014.213a

Chetty, N. D. S., Handayani, L., Sahabudin, n. a., Ali, Z., Hamzah, N., \& Kasim, S. (2019). Learning Styles and Teaching Styles Determine Students' Academic Performances. Journal of Evaluation and Research in Education (IJERE), 8(4), 25-32. doi: org/10.11591/ijere.v8i4.20345

Crebert, G. Bates, M., Bell, B., Patrick, C., \& Cragnolini, V. (2004). Developing generic skills at university, during work placement and in employment: graduates' perceptions. Higher Education Research \& Development, 23(2), 147-165. doi.org/10.1080/0729436042000206636

Creed, P., Buys, Tilbury \& Crawford. (2013). The relationship between goal orientation and career striving in young adolescents," Journal of Applied Social Psychology, 43(7), 1480-1490.

doi: $10.1111 /$ jasp. 1210

Editors, (2017). School daze: As US states turn the screw on science education, researchers everywhere should pay more attention to how their subject is presented," Nature, 543, 149.

Goethe, O. (2019). Learning Experiences in Real Life. In O. Goethe, Gamification Mindset, (pp. 14-20). Switzerland: Springer Nature Switzerland AG 2019.

Gregor, M., O’Brien, K. M, Sauber, E. (2017). Understanding Career Aspirations Among 


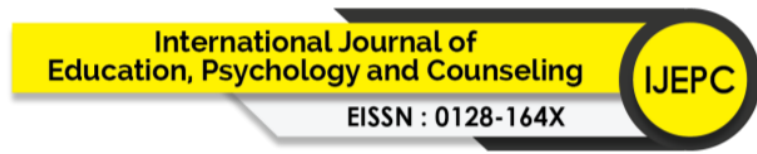

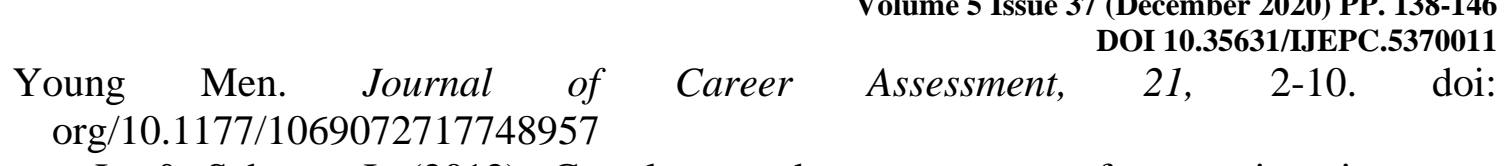

Gutman, L. \& Schoon, I. (2012). Correlates and consequences of uncertainty in career aspirations: Gender differences among adolescents in England. Journal of Vocational Behavior, 80, 608-618.

Hee, O. C., Shi, C. H., Kowang, T. O., Fei, G. C., \& Ping, L. L. (2020). Factors influencing job satisfaction among academic staffs: Evidence from Malaysia. International Journal of Evaluation and Research in Education (IJERE), 9(2), 89-97. doi: 10.11591/ijere.v9i2.20509

Hubahib, R. (2016). Students' Performance in Inquiry and Hands-On Activities on Eating and Exercis. Mancester City: MSU-Iligan Institute of Technology.

Husin, M. R., Shukor, A. A., Jusoh, A. J. (2011). Gaya Pembelajaran dan Persekitaran yang Mempengaruhi Murid Sukar Belajar Dalam Mata Pelajaran Pendidikan Islam. Jurnal Penyelidikan Dedikasi, 11, 98-111.

Husin, M. R. (2017). Exploring the Use of Digital Devices among Pupils with Learning Disabilities," International Journal of Multimedia and its Applications, 9, 75-86.

Husin, M. R. (2018a). Video Application Model in Learning Styles of Moral Education Students in Teacher Educational Institution. International Journal of Engineering and Technology (UAE), 7, 21-26.

Husin, M. R. (2018b). Making Short Video and Multi-Sensory Instructional Packages for Moral Education Courses in Teacher Education Institutes," Global Journal Of Advanced Engineering Technologies And Sciences, 5, 9-18.

Husin, M. R., Ahmad, H., Panessai, I. Y., Majid, N. A., \& Sulam, A. L. (2020). Inductive instructional approach, career aspiration and noble values in history. International Journal of Evaluation and Research in Education (IJERE), 9(1), 162-167.doi: 10.11591/ijere.v9i1.20417

Idris, N. (2010). Penyelidikan dalam pendidikan. Kuala Lumpur: McGraw Hill.

Ismail, Z., Kadir, S. A. \& Pihie, Z. A. L. (2011). Career Aspiration among Secondary School Accounting Students in Selangor," International Conference on Humanities, Society and Culture IPEDR. 20, 1-8.

Jony, M. (2019). Exploring the Effectiveness of Cooperative Learning at Secondary Level in Bangladesh" International Journal of Educational Research Review, 5, 93-99.

Jufrida J., Basuki, F. R., Kurniawan, W., Pangestu, M. D., Fitaloka, O. (2019). Scientific literacy and science learning achievement at junior high School. International Journal of Evaluation and Research in Education (IJERE), 8(4), 106-204.doi: org/10.11591/ijere.v8i4.20312

Kementerian Pendidikan Malaysia. (2015). Dokumen standard kurikulum dan pentaksiran. Kuala Lumpur: Bahagian Pendidikan Guru.

Merriam S. (2001). Qualitative research and Case Study Applications in Education. San Francisco: Jossey-Bass Pub.

Miles, M. \& Huberman, M. (1984). Qualitative data analysis: A source book for new methods. Beverly Hills, CA: Sage Publications.

Peterson, S. \& Scott, S. (2018). As part of the Improved Methods for Teaching Science. School Science Review, 71, 63-72.

Sampangi, R. \& Siegel, A. (2019). Designing Engaging Learning Experiences. in The 2019 ACM Conference, 10-18.

Selvam, T. (2017). Career Aspiration Among Rural Undergraduate Students. International Research Journal of Human Resources and Social Sciences, 4, 21-27. 


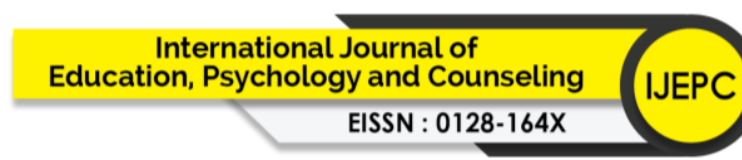

Volume 5 Issue 37 (December 2020) PP. 138-146

DOI 10.35631/IJEPC.5370011

Shola, B. (2019). The non-technical skills needed by graduates of technical colleges in metalwork technology for future Employment. International Journal of Evaluation and Research in Education (IJERE), 8, 98-106.

Shukor, A. A., Husin, M. R., Jusoh, A. J. (2015). Stimulus Gaya Pembelajaran Murid Sukar Belajar Dalam Mata Pelajaran Pendidikan Islam. Jurnal Dedikasi, 9, 59-76.

Silveira L. G. F., Munford, D. (2020). Article Science learning: an analysis of discursive interactions and different space-temporal dimensions in the classroom daily life. Brasileira de Educação, 25, 1-31.doi.org/10.1590/s1413-24782020250015

Tripney, J., Newman, Bangpan, Niza, MacKintosh \& Sinclair. (2010). Factors Influencing Young People (Aged 14-19) in Education about STEM Subject Choices: A Systematic Review of the UK Literature" Evidence for Policy and Practice Information and CoOrdinating Centre. London: Institute of Education, University of London.

Tladinyane, R \& Merwe, M. (2016). Career adaptability and employee engagement of adults employed in an insurance company: An exploratory study. SA Journal of Human Resource Management, 14, 752.

Tsuda, K. (1974). Nursing related to daily life. Kango kyoshitsu [Nursing classroom, 18, 145.

Ueki, R. (2013). Ideal Ways to Teach Students How to Utilize Self-Monitoring Strategies. Japanese Journal of Educational Psychology, 52, 277-286.

Walan, S. (2017). Teaching children science through storytelling combined with hands-on activities - a successful instructional strategy" Article in Education, 3, 13-15.

Wamb, N. \& Dunn, K. (2009). Effective Individualized Educational Plans: Do Something Special with Learning Styles. Insights on Learning Disabilities, 6, 1-11.

Widodo, W. (2016). Assessing the Readiness of Student Learning Acitivity and Learning Outcome. Jurnal Pencerahan, 10, 81-94.

Wijaya, O. \& Bukhori, I. (2017). Effect of Learning Motivation, Family Factor, School Factor, and Community Factor on Student Learning Outcomes on Productive Subject. Jurnal Pendidikan Bisnis dan Manajemen, 3, 192-202.

Zenda, R. (2017). Essential teaching methods to enhance learner academic achievement in physical sciences in rural secondary schools: A South African case study. Educational Research, 53, 439-457. 